\title{
Imaging stent-thrombus interaction in mechanical thrombectomy
}

Figure MicroCT, scanning electron and light microscopy of thrombus caught in a stentriever
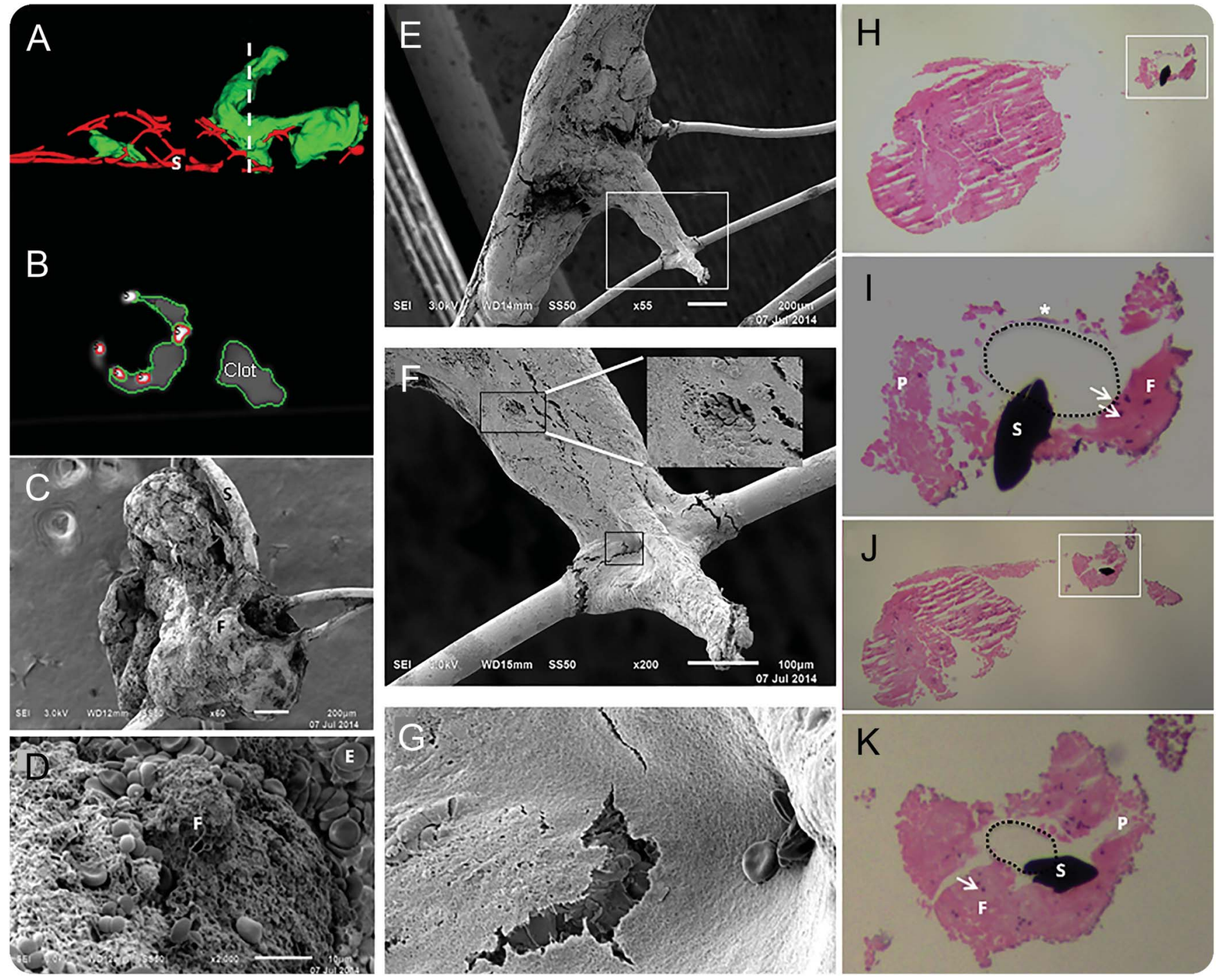

MicroCT (A, B) illustrates thrombus (green) caught in the stentriever. Scanning electron microscopy illustrates complexity and variability in thrombus surface consisting of fibrin, erythrocytes, and platelets (C, D). Furthermore, thrombus stabilization by fibrin is shown (E-G). Histology (I-K) shows thrombus consisting of fibrin and platelet-rich areas with interspersed leukocytes, coalescing around the wire. $E=$ erythrocytes; $F=$ fibrin; $P=p l a t e l e t s ; S=$ stent wire. Arrows in $\mathrm{I}, \mathrm{K}=$ leukocytes. Star in I = leukocyte adhering to a wire.

A 52-year-old man had a right M1 occlusion, treated with mechanical intra-arterial therapy. After 5 minutes of intra-arterial embedding, the stentriever containing thrombus was retrieved, rinsed, and fixed for microscopy. MicroCT scanning electron and light microscopy was performed on the stentriever to assess stent-thrombus interaction (figure). Twenty-three sites of interaction between thrombus and stentriever were analyzed. Interaction was not mechanical at 12 of these sites. We observed fibrin cross-bridges connecting thrombus to stent wires. Fibrin also created smooth covers overlying erythrocyte-rich areas. Light microscopy further showed thrombus interspersed with leukocytes, consisting of fibrin- and platelet-rich areas coalescing around the stent wire. 
Adriaan C.G.M. van Es, MD, PhD, Anouchska S.A. Autar, MD, Bart J. Emmer, MD, PhD, Geert J. Lycklama à Nijeholt, MD, PhD, Bas F.W. van der Kallen, MD, Heleen M.M. van Beusekom, MD, PhD

From Erasmus MC Rotterdam (A.C.G.M.v.E., A.S.A.A., B.J.E., H.M.M.v.B.); and MCHaaglanden (G.J.L.à.N., B.F.W.v.d.K.), 's Gravenhage, the Netherlands.

Author contributions: Design or conceptualization of the study: A.C.G.M.v.E., A.S.A.A., B.J.E., G.J.L.à.N., B.F.W.v.d.K., H.M.M.v.B. Analysis or interpretation of the data: A.C.G.M.v.E., A.S.A.A., B.J.E., G.J.L.à.N., B.F.W.v.d.K., H.M.M.v.B. Drafting or revising the manuscript for intellectual content: A.C.G.M.v.E., A.S.A.A., B.J.E., G.J.L.à.N., B.F.W.v.d.K., H.M.M.v.B.

Study funding: No targeted funding reported.

Disclosure: The authors report no disclosures relevant to the manuscript. Go to Neurology.org for full disclosures

Correspondence to Dr.van Beusekom: h.vanbeusekom@erasmusmc.nl

\section{Subspecialty Alerts by E-mail!}

Customize your online journal experience by signing up for e-mail alerts related to your subspecialty or area of interest. Access this free service by visiting Neurology.org/site/subscriptions/etoc.xhtml or click on the "E-mail Alerts" link on the home page. An extensive list of subspecialties, methods, and study design choices will be available for you to choose from—allowing you priority alerts to cutting-edge research in your field!

\section{Save These Dates for AAN CME Opportunities!}

Mark these dates on your calendar for exciting continuing education conferences by the American Academy of Neurology. Learn more at AAN.com/conferences.

Breakthroughs in Neurology

- January 13-16, 2017, Phoenix, AZ, at the Sheraton Grand at Wild Horse Pass AAN Annual Meeting

- April 22-28, 2017, Boston, MA, at the Boston Convention Center

\section{Share Your Artistic Expressions in Neurology 'Visions'}

AAN members are urged to submit medically or scientifically related artistic images, such as photographs, photomicrographs, and paintings, to the "Visions" section of Neurology ${ }^{\circledR}$. These images are creative in nature, rather than the medically instructive images published in the NeuroImages section. The image or series of up to six images may be black and white or color and must fit into one published journal page. Accompanying description should be 100 words or less; the title should be a maximum of 96 characters including spaces and punctuation.

Learn more at www.ann.com/view/Visions, or upload a Visions submission at submit.neurology.org. 


\section{Neurology}

\section{Imaging stent-thrombus interaction in mechanical thrombectomy \\ Adriaan C.G.M. van Es, Anouchska S.A. Autar, Bart J. Emmer, et al. \\ Neurology 2017;88;216-217 \\ DOI 10.1212/WNL.0000000000003487}

This information is current as of January 9, 2017

\begin{tabular}{|c|c|}
\hline $\begin{array}{l}\text { Updated Information \& } \\
\text { Services }\end{array}$ & $\begin{array}{l}\text { including high resolution figures, can be found at: } \\
\text { http://n.neurology.org/content/88/2/216.full }\end{array}$ \\
\hline Subspecialty Collections & $\begin{array}{l}\text { This article, along with others on similar topics, appears in the } \\
\text { following collection(s): } \\
\text { All Cerebrovascular disease/Stroke } \\
\text { http://n.neurology.org/cgi/collection/all_cerebrovascular_disease_strok } \\
\text { e } \\
\text { Embolism } \\
\text { http://n.neurology.org/cgi/collection/embolism } \\
\text { Infarction } \\
\text { http://n.neurology.org/cgi/collection/infarction }\end{array}$ \\
\hline Permissions \& Licensing & $\begin{array}{l}\text { Information about reproducing this article in parts (figures,tables) or in } \\
\text { its entirety can be found online at: } \\
\text { http://www.neurology.org/about/about_the_journal\#permissions }\end{array}$ \\
\hline Reprints & $\begin{array}{l}\text { Information about ordering reprints can be found online: } \\
\mathrm{http} / / / \mathrm{n} \text {.neurology.org/subscribers/advertise }\end{array}$ \\
\hline
\end{tabular}

Neurology ${ }^{\circledR}$ is the official journal of the American Academy of Neurology. Published continuously since 1951, it is now a weekly with 48 issues per year. Copyright (O 2017 American Academy of Neurology. All rights reserved. Print ISSN: 0028-3878. Online ISSN: 1526-632X.

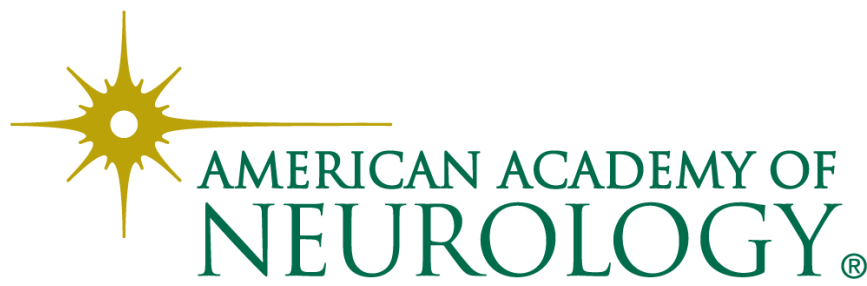

